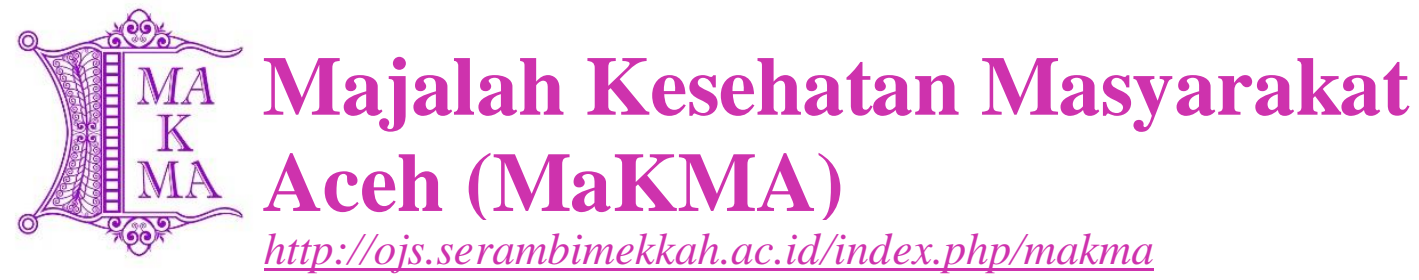

\title{
SOLONG SERGAP (SOLONG SETOR SAMPAH CEGAH ISPA) SEBAGAI UPAYA PEMBERDAYAAN MASYARAKAT LINGKUNGAN SOLONG, BANYUWANGI
}

\author{
Rizky Putri Hariyani ${ }^{1}$, Ayik Mirayanti Mandagi ${ }^{2}$, Hodimatum Mahiro ${ }^{3}$, Ayu Fitri \\ Lestari $^{3}$
}

${ }^{1}$ Fakultas Kesehatan Masyarakat, Universitas Airlangga PSDKU Banyuwangi

${ }^{\bowtie}$ Alamat Korespondensi: J1. Wijaya Kusuma No.113 Lingkungan Cungking, Mojopanggung, Giri, Banyuwangi / rputriiii01@gmail.com / 089650464213

\begin{abstract}
ABSTRAK
Menurut WHO (2016) kasus ISPA di dunia sebanyak 18,8 miliar dan menyebabkan kematian sebanyak 4 juta orang per tahun. Berdasarkan data dari Puskesmas Klatak pada tahun 2016 hingga 2017 Infeksi Saluran Pernapasan Akut merupakan peringkat pertama dalam 10 besar tertinggi daftar penyakit yang ada, faktor pendukungnya yaitu kepadatan penduduk, kepadatan hunian, polusi udara dan sanitasi lingkungan yang buruk. Berdasarkan FGD awal yang dilakukan bersama masyarakat dan aparat desa Kelurahan Klatak, masyarakat menilai bahwa kualitas udara sekitar adalah pemyebab terbesarnya. Lingkungan Solong, kelurahan Klatak diduga sebagai wilayah dengan dampak pencemaran udara tertinggi akibat lokasinya yang dekat dengan area industri pabrik dan pembakaran sampah ilegal yang dilakukan oleh warga setempat. Tujuan Program Solong Sergap adalah untuk meningkatkan kapasitas pengetahuan mengenai pemilahan dan pengolahan sampah hingga praktek dalam mengolah sampah. Melalui artikel ini, penulis menyampaikan perencanaan hingga implementasi Program Solong Sergap berdasarkan Teori Dignan. Metode yang dilakukan yaitu secara observasional menggunakan pendekatan kualitatif dengan jenis penelitian yang bersifat deskriptif. Hasil dari kegiatan ini yaitu terbentuknya kelompok Solong Sergap yang bertugas untuk mengontrol penyetoran sampah baik organik maupun anorganik. Indikator keberhasilan kegiatan ini yaitu tingkat kehadiran peserta dalam kegiatan Solong Sergap sebesar 75\%, peserta Solong Sergap mampu memilah sampah anorganik dan organik dan peserta Solong Sergap menyetor sampah anorganik tiap 2 hari sekali. Berdasarkan indikator keberhasilan yang ada, kegiatan ini sudah mencapai target. Kesimpulan yang didapatkan yaitu program Solong Sergap cukup efektif dalam mengurangi frekuensi pembakaran sampah di Lingkungan Solong. Saran yang dapat diberikan yaitu intensitas komuniaksi penanggung jawab kegiatan lebih sering kepada peserta kegiatan yang bertujuan supaya kegiatan berkelanjutan.
\end{abstract}

Kata Kunci: ISPA, Sampah, Teori Dignan.

Riwayat Artikel

Diterima : 03 Juli 2019

Disetujui : : 30 Juli 2019

Dipublikasi : : 31 Juli 2019 


\title{
SOLONG SERGAP (SOLONG SETOR SAMPAH CEGAH ISPA) AS THE EMPOWERMENT EFFORTS OF THE COMMUNITY OF LINGKUNGAN SOLONG, BANYUWANGI
}

\begin{abstract}
According to WHO 2016, URTI (Upper Respiratory Tract Infection) cases in the world are 18.8 billion and cause the deaths of as many as 4 million people per year. Based on data from the Klatak Health Center in 2016 to 2017 Acute Respiratory Infections is ranked first in the top 10 highest list of existing diseases, the supporting factors are population density, occupancy density, air pollution and poor environmental sanitation. Based on the initial FGD conducted with the community and village officials from the Klatak Village, the community considered that the surrounding air quality was the biggest cause. Environment Solong, Klatak village is suspected of being the region with the highest impact of air pollution due to its location near the factory industrial area and illegal burning of garbage carried out by local residents. The aim of the Solong Sergap Program is to increase the capacity of knowledge regarding sorting and processing waste to practice in processing waste. Through this article, the author delivers planning to the implementation of the Solong Sergap Program based on Dignan Theory. The method used is observational using a qualitative approach with a type of descriptive research. The results of this activity are the formation of the Solong Sergap group which is in charge of controlling the deposit of both organic and inorganic waste. The indicator of the success of this activity is the level of attendance of participants in Solong Sergap activities by 75\%, Solong Sergap participants able to sort inorganic and organic waste and Solong Sergap participants deposit inorganic waste every 2 days. Based on existing indicators of success, this activity has reached the target. The conclusion obtained is that the Solong Sergap program is quite effective in reducing the frequency of waste burning in the Solong Environment. Suggestions that can be given are the intensity of communication of the person in charge of the activity more often to the participants of the activity aimed at continuing activities
\end{abstract}

Keywords: URTI, Waste, Dignan Theory. 


\section{PENDAHULUAN}

Infeksi Saluran Pernapasan Akut (ISPA) merupakan penyakit yang sering dijumpai di masyarakat dengan gejala ringan sampai berat ${ }^{[1]}$. Penyakit ISPA menjadi penyebab utama morbiditas dan mortalitas penyakit menular di dunia. Menurut WHO kasus ISPA di seluruh dunia sebanyak 18,8 miliar dan menyebabkan kematian sebanyak 4 juta orang per tahun ${ }^{[2]}$. Berdasarkan profil kesehatan Indonesia tahun 2017, didapatkan insiden (per 1000 balita) di Indonesia sebesar 20,54 ${ }^{[3]}$. Tingkat mortalitas penyakit ISPA sangat tinggi pada balita, anak-anak, dan orang lanjut usia terutama di negara-negara dengan pendapatan per kapita rendah dan menengah $^{[4]}$.

Penelitian yang dilakukan sejak tahun 2003 hingga tahun 2013 menyatakan bahwa di Nigeria faktor risiko kejadian ISPA adalah kepadatan penduduk, kepadatan hunian, polusi udara dan sanitasi lingkungan yang buruk $^{[5]}$. Pemukiman kumuh Kota Dibrugarh banyak faktor yang mempengaruhi kejadian gangguan pernafasan pada balita seperti pemberian polusi udara, ASI ekslusif, imunisasi, sosial ekonomi, dan tingginya tingkat pencemaran udara ${ }^{[6]}$. Dapat dilihat bahwa kualitas udara juga merupakan salah satu faktor determinan penyebab terjadinya ISPA.

\section{METODE}

Berdasarkan pada studi awal yang telah dilakukan, Lingkungan Solong dipilih sebagai lokasi implementasi Program Solong Sergap. Lokasi spesifik ada di Lingkungan Solong RT 2 dan RT 3. Lokasi ditentukan berdasarkan data yang telah diperoleh dan menunjukkan bahwa 2
Berdasarkan data dari Puskesmas Klatak pada tahun 2016 hingga 2017 Infeksi Saluran Pernapasan Akut merupakan peringkat pertama dalam 10 besar tertinggi daftar penyakit yang ada ${ }^{[7]}$. Pasien ISPA di Puskesmas Klatak pada tahun 2018 meningkat dari bulan Januari hingga Maret dan selanjutnya menurun hingga juni. Dari keseluruhan pasien ISPA yang berkunjung ke Puskesmas Klatak, jenis kelamin laki-laki mendominasi dengan usia paling banyak adalah kelompok balita. Menurut persebaran wilayah, paling banyak pasien dari lingkungan Klatakan dan Solong. Berdasarkan dengan masalah tersebut, perlu dilakukan kegiatan yang dapat memberikan kemandirian pada masyarakat untuk mencegah terjadinya ISPA. Kegiatan yang diberikan bernama Solong Sergap (Solong Setor Sampah Cegah Ispa). Beberapa tujuan khusus dari kegiatan atau program ini adalah membangun partisipasi masyarakat untuk turut serta dalam program Solong SERGAP, peserta mampu memilah sampah anorganik dan organic, peserta mampu mengolah sampah organik menjadi pupuk. Melalui tulisan ini, penulis akan menyampaikan mengenai perancangan hingga implementasi program berdasarkan dengan Teori Dignan.

lokasi tersebut memiliki jumlah warga dengan ISPA tertinggi di Klatak. Waktu pelaksanaan kegiatan ini yaitu tanggal 30 Juli hingga 4 Agustus 2018. Sumber data yang telah didapatkan yaitu merupakan hasil pengamatan observasional secara langsung. Metode analisis yang digunakan dalam implementasi program pemberdayaan 
masyarakat ini yaitu berdasarkan dengan Teori Dignan ${ }^{[8]}$. [Gambar 1]

\section{HASIL}

Program Solong Sergap merupakan program pemberdayaan masyarakat daerah Solong guna mengurangi masalah mengenai ISPA yang diakibatkan oleh kualitas udara sekitar. Warga masyarakat Solong masih sering melakukan pembakran sampah rumah tangga secara rutin di sekitar rumah. Program ini terdari dari beberapa pelaksanaan kegiatan. Kegiatan pertama yaitu Solong Sergap 1 yang merupakan permasalahan, pemaparan program dan sesi diskusi. Kegiatan berlangsung lancar, peserta sangat antusias dalam mengikuti kegiatan terutama pada sesi diskusi. Hasil diskusi pada Solong Sergap 1 menghasilkan penguatan komitmen pemuda dan ibu-ibu PKK terkait pelaksanaan program Solong Sergap secara berkelanjutan, selain itu penetapan hari dan tempat pelaksanaan pertemuan Solong Sergap 2 pun telah disepakati. Kegiatan selanjutnya yang dilakukan yaitu Solong Sergap 2 yang meliputi kegiatan penyampaian materi terkait sampah organik dan anorganik beserta pemilahannya dan praktikum membuat pupuk dari sampah organik rumah tangga. Antusias peserta cukup tinggi, peserta mengikuti serangkaian kegiatan dengan baik, mulai dari tahap persiapan bahan-bahan hingga pembuatan pupuk organik. Kondisi di lapangan cukup terarah namum tidak sepenuhnya kondusif karena lokasi yang berada di lapangan sehingga

\section{PEMBAHASAN}

Program Solong Sergap bertujuan untuk mencegah bertambahnya pasien ISPA di daerah Solong dengan cara memperbaiki kualitas udara sekitar. Selain tujuan tersebut, kegiatan ini juga dimaksudkan untuk memberdayakan mengundang banyak anak kecil yang mendekat pada titik pembuatan pupuk organik saat proses pembuatan cukup mengganggu ruang gerak mahasiswa dan peserta. Setelah diadakan kegiatan ini, ibu-ibu PKK cukup terpicu untuk melanjutkannya. Kegiatan Solong Sergap 2 ditutup dengan penyerahan pupuk organik buatan pemuda dan ibuibu PKK kepada ketua RW dan RT.

Kegiatan Solong Sergap merupakan kependekan dari Solong Setor Sampah Cegah ISPA. Tujuan dari kegiatan ini yaitu sebagai upaya minimalisasi frekuensi pembakaran sampah oleh masyarakat Lingkungan Solong. Kegiatan ini merupakan kegiatan pemberdayaan masyarakat dengan sasaran masyarakat Lingkungan Solong, Kelurahan Klatak, Kabupaten Banyuwangi. Target kegiatan ini adalah 1 kelompok yang terdiri dari 10 hingga 20 orang yang berada di wilayah RT 2 dan RT 3 Lingkungan Solong. Tujuan kegiatan ini adalah untuk menambah pengetahuan mengenai sampah maupun ISPA dan pelatihan mengenai pemilihan dan pengolahan sampah pada masyarakat Lingkungan Solong melalui kegiatan sosialisasi dan pelatihan. Indikator keberhasilan kegiatan ini yaitu tingkat kehadiran peserta dalam kegiatan Solong Sergap sebesar 75\%, peserta Solong Sergap mampu memilah sampah anorganik dan organik dan peserta Solong Sergap menyetor sampah anorganik tiap 2 hari sekali.

masyarakat sekitar daerah Solong untuk lebih memahami cara memilah dan mengolah sampah. Pengolahan sampah oleh masyarakat juga dimaksudkan untuk memberikan kontrobusi untuk membangun perekonomian di tempat kegiatan. Perencanaan dan pelaksanaan 
program ini didasari pada kerangka teori dignan sehingga gagasan yang diusulkan sesuai dengan keadaan masyarakat dan sesuai dengan nilai-nilai yang dianut masyarakat.

\section{Community Analysis}

Tahap awal pada kerangka dignan yaitu community analysis. Community analysisi merupakan tahapan dimana peneliti akan melakukan analisis mengenai aspek yang ada pada masyarakat seperti keadaan sosial, pendidikan, mata pencaharian, masalah kesehatan, kondisi lingkungan, fasilitas pelayanan kesehatan dan aspek lainnya yang dapat mempengaruhi (Dignan \& Carr, 1992). Analisis yang didapatkan mayoritas mayarakat mengeluhkan masalah lingkungan. Berdasarkan hasil observasi langsung, masalah terbanyak yang dikeluhkan oleh warga yaitu mengenai pembakaran sampah dan kurangnya pengetahuan masyarakat mengenai pemilahan dan pengolahan sampah. Sampah yang dihasilkan oleh kegiatan masyarakat sekitar biasanya langsung dibakar saja. Frekuensi pembakaran sampah yang dilakukan masyarakat sangat beragam. Beberapa masyarakat mengatakan bahwa kegiatan pembakaran sampah yang mereka lakukan bisa saja setiap hari jika memang sampah yang dihasilkan berjumlah banyak. Masyarakat juga banyak yang belum memahami hubungan antara pembakaran sampah dengan kualitas udara sekitar maupun dengan ISPA. Beberapa faktor yang dapat mempengaruhi keadaan ini yaitu seperti kurangnya pemahaman masyarakat mengenai sampah, tidak adanya fasilitas yang mendukung, dan kurangnya sumber daya yang baik dari swasta maupun pemerintah yang memfasilitasi pemberdayakan masyarakat di lingkungan ini.

\section{Targeted Assessment}

Targeted assessment dilakukan sebagai identifikasi sasaran program, golongan masyarakat yang seperti apa yang paling membutuhkan program yang akan dilakukan. Tahapan ini akan menilai sasaran secara spesifik yang akan diintervensi melalui program pemberdayaan ini. Penilaian sasaran dilakukan dengan memperhatikan jumlah sasaran yang akan diintervensi, lokasi strategis dari kegiatan yang akan dilakukan, jenis kelamin sasaran, kualitas sumber daya yang dimiliki, pekerjaan, dan pendidikan, serta perubahan perilaku yang diinginkan. Targeted assessment bersifat lebih subyeksional jika dibandingkan dengan community analysis yang masih memahami masalah secara glob-al (Dignan \& Carr, 1992).

Lokasi diambil di daerah Lingkungan Solong karena merupakan lingkungan yang paling padat penduduk dibandingkan dengan lingkungan lainnya. Pemahaman masyarakat lingkungan solong juga tergolong cukup hingga kurang mengenai sampah. Terdapat beberapa RT di Lingkungan Solong, disetiap RT memiliki kelompok PKK masing-masing. Sasaran spesifik pada kegiatan ini yaitu pada perwakilan masyarakat wilayah Solong Rt 2 dan RT 3 yang memiliki keinginan dan kemampuan dalam mengikuti kegiatan. Kelompok yang telah ditunjuk akan diberikan intervensi dengan program Solong Sergap sebagai intervensi peningkatan pengetahuan dan proses perubahan perilaku yang diinginkan melalui pemberian sosialisasi mengenai sampah dan pelatihan dalam mengolah sampah.

\section{Program Plan Development}

Tahap ini merupakan tahapan dimana program direncanakan secara 
matang sebelum dilakukan intervensi. Terdapat beberapa perencanaan yang dilakukan secara spesifik pada tahap ini, misalnya mengenai lokasi kegiatan, alat dan bahan yang digunakan, rencana implementasi yang akan dilaksanakan dengan memperhatikan dasar teori perubahan perilaku (Dignan \& Carr, 1992). Teori perubahan perilaku yang digunakan yaitu dengan teori S-O-R. Teori ini digunakan dengan alasan yaitu sesuai dengan kondisi yang ada di masyarakat Solong. Guna mendapatkan perubahan perilaku masyarakat terutama kelompok PKK dalam mengelola sampah diperlukan suatu proses belajar yang saling berkelanjutan. Terdapat 3 hal yang mendasari Teori S-O-R yaitu :

Stimulus

Stimulus berupa rangsangan yang mengandung pesan atau gagasan baru yang diberikan oleh stimulator mengenai penekanan angka kejadian ISPA. Mengenai kasus yang diambil yaitu mengenai pengurangan pembakaran sampah guna mencegah ISPA pada balita, diberikan rangsangan oleh mahasiswa mengenai pemilahan dan pengolahan sampah organik pada masyarakat. Rangsangan awal yang diberikan yaitu bagaimana pemilahan sampah organik dan anorganik, menyetor sampah anorganik ke Ketua RT di Wilayah Solong, dan mengolah sampah organik menjadi pupuk dengan cara mengolahnya secara mandiri di tempat sekitar.

Organisme

Organisme merupakan target yang persuasif dalam keberlanjutan program yang telah dibuat. Pembuat program merencanakan organisme yang ditunjuk yaitu beberapa perwakilan masyarakat wilayah Solong yang memiliki keinginan dan kemampuan dalam mengikuti Solong Sergap. Jumlah partisipan yang diikutkan atau kelompok pemicu yaitu sebesar 10 hingga 20 peserta dalam 1 kelompok.

\section{Respon}

Respon disini artinya yaitu efek yang diharapkan atas stimulasi yang telah diberikan. Respon dalam kegiatan ini yaitu masyarakat Lingkungan Solong yang lain mampu mengelola sampah yang awalnya dibakar menjadi suatu hal yang lebih bermanfaat untuk kedepannya sehingga program dapat berkelanjutan. Serta masyarakat lingkungan Solong mampu memilah sampah yang dapat didaur ulang dan dikumpulkan kepada Tim Solong Sergap.

\section{Implementation}

Pelaksanaan kegiatan Solong Sergap berjalan dengan lancar sesuai dengan yang telah direncanakan. Hal tersebut dapat dilihat dari ketercapaian indikator keberhasilan program, yaitu pada implementasinya

\section{Solong Sergap 1}

Program Solong Sergap 1 dilaksanakan pada tanggal 30 Juli 2018 dengan jumlah 26 peserta yang terdiri dari pemuda Solong dan ibu-ibu PKK bertempatan di rumah koodinator program Solong Sergap. Pertemuan Solong Sergap 1 berlangsung selama 60 menit. Acara dimulai pukul 16.00 WIB berdasar susunan acara yang telah ditetapkan, namun pada pelaksanaannya kegiatan Solong Sergap 1 mundur kurang lebih 30 menit. Susunan acaranya meliputi pemaparan permasalahan, pemaparan program dan sesi diskusi. Kegiatan berlangsung lancar, peserta sangat antusias dalam mengikuti kegiatan terutama pada sesi diskusi. Hasil diskusi pada Solong Sergap 1 menghasilkan penguatan 
komitmen pemuda dan ibu-ibu PKK terkait pelaksanaan program Solong Sergap secara berkelanjutan, selain itu penetapan hari dan tempat pelaksanaan pertemuan Solong Sergap 2 telah disepakati.

\section{Solong Sergap 2}

Kegiatan ini merupakan keberlanjutan dari pertemuan Solong Sergap 1 yang menghasilkan penguatan komitmen pemuda dan ibu-ibu PKK. Kegiatan Solong Sergap 2 dilaksanakan pada tanggl 4 Agustus 2018 bertempat di lapangan Lingkungan Solong, dihadiri oleh pemuda dan ibu-ibu PKK sejumlah 18 orang. Kehadiran peserta memenuhi target kelompok yang hanya menetapkan 10 peserta saja untuk mengikuti kegiatan pada Solong Sergap 2. Susunan acara dalam Solong Sergap 2 meliputi penyampaian materi terkait sampah organik dan anorganik beserta pemilahannya dan praktik membuat pupuk dari sampah organik rumah tangga. Antusias peserta cukup tinggi, peserta mengikuti serangkaian kegiatan dengan baik, mulai dari tahap persiapan bahan-bahan hingga pembuatan pupuk organik. Kondisi di lapangan cukup terarah namum tidak sepenuhnya kondusif karena lokasi yang berada di lapangan sehingga mengundang banyak anak kecil yang mendekat pada titik pembuatan pupuk organik saat proses pembuatan cukup mengganggu ruang gerak mahasiswa dan peserta. Setelah diadakan kegiatan ini, ibu-ibu PKK cukup terpicu untuk melanjutkannya. Kegiatan Solong Sergap 2 ditutup dengan penyerahan pupuk organik buatan pemuda dan ibu-ibu PKK kepada ketua RW dan RT.

\section{Evaluation}

Evaluasi dalam Teori Dignan terdiri atas evaluasi proses dan evaluasi hasil. Evaluasi proses pelaksanaan program Solong Sergap dapat dilihat melalui implementasi kegiatan tersebut. Seperti yang telah disebutkan bahwa kegiatan solong Sergap 1 mundur sekitar 30 menit dari rundown yang telah dibuat. Masyarakat sangat antusias dalam mengikuti kegiatan tersebut. Hal tersebut dapat dilihat melalui aktifnya tanya jawab yang dilakukan oleh masyarakat dengan pemateri mengenai cara pemilahan, dan pengolahan sampah. Pelaksanaan Solong Sergap 2 tergolong sukses, hal ini dapat dilihat dari antusias warga dalam pengikuti pelatihan pembuatan pupuk dari sampah dan tanya jawab masyarakat mengenai pembuatan.

\section{KESIMPULAN DAN SARAN}

Solong Sergap merupakan suatu program yang dilakukan oleh mahasiswa kepada masyarakat Lingkungan Solong guna mengurangi frekuensi pembakaran sampah. Partisipasi masyarakat dalam mengikuti kegiatan ini tergolong aktif, dibuktikan dengan antusiasme masyarakat dalam berpartisipasi. Dilihat dari implementasi program, peserta telah mampu memilah antara sampah anorganik dan sampah organik. Setelah pemilahan sampah dilakukan, sampah anorganik disetorkan kepada penanggung jawa yaitu ketua RT. Sampah organik yang terkumpul lalu diolah menjadi pupuk kompos oleh masyarakat Lingkungan Solong. Kegiatan ini diharapkan bisa berkelanjutan guna mengurangi frekuensi pembakaran sampah di Lingkungan Solong. Agar kegiatan ini dapat berkelanjutan, sebaiknya kelompok penanggung jawab yang terdiri dari pemuda dan ibu-ibu PKK meningkatkan komunikasinya dengan pihak yang mau berpartisipasi dalam kegiatan ini secara intensif. 


\section{DAFTAR PUSTAKA}

1. Kementrian Kesehatan Republik Indonesia. Profil Kesehatan Indonesia. Jakarta. Kementrian Kesehatan RI (2009)

2. WHO. Pneumonia. Geneva: World Health Organization. (2016)

3. Kementrian Kesehatan Republik Indonesia. Profil Kesehatan Indonesia. Kementrian Kesehatan RI. Jakarta : (2017).

4. WHO. Infeksi saluran pernapasan akut (ISPA) yang cenderung menjadi epidemi dan pandemic. Jenewa. Organisasi Kesehatan Dunia (World Health Organization). Jenewa : (2017)

5. Akinyemi, Joshua Oduyano dan Oyewale Mayowa Morakinyo. Household environment and symptoms of childhood acute respiratory tract infections in Nigeria, 2003-2013: a decade of progress and stagnation. University of Ibadan (2018)

6. Nirmolia, N., Mahanta, T. G., Boruah, M., Rasaily, R., Kotoky, R. P., \& Bora, R. (2018). Prevalence and risk factors of pneumonia in under five children living in slums of Dibrugarh town. Clinical Epidemiology and Global Health, 6(1), 1-4.

7. Puskesmas Klatak. 2018. Profil Puskesmas Klatak. Banyuwangi. Puskesmas Klatak

8. Dignan, M.B., and Carr, P. A. 1992. Program Planning for Health Educational adan Promotion 2 nd Edition. USA: Lea and Febiger. 


\section{LAMPIRAN}

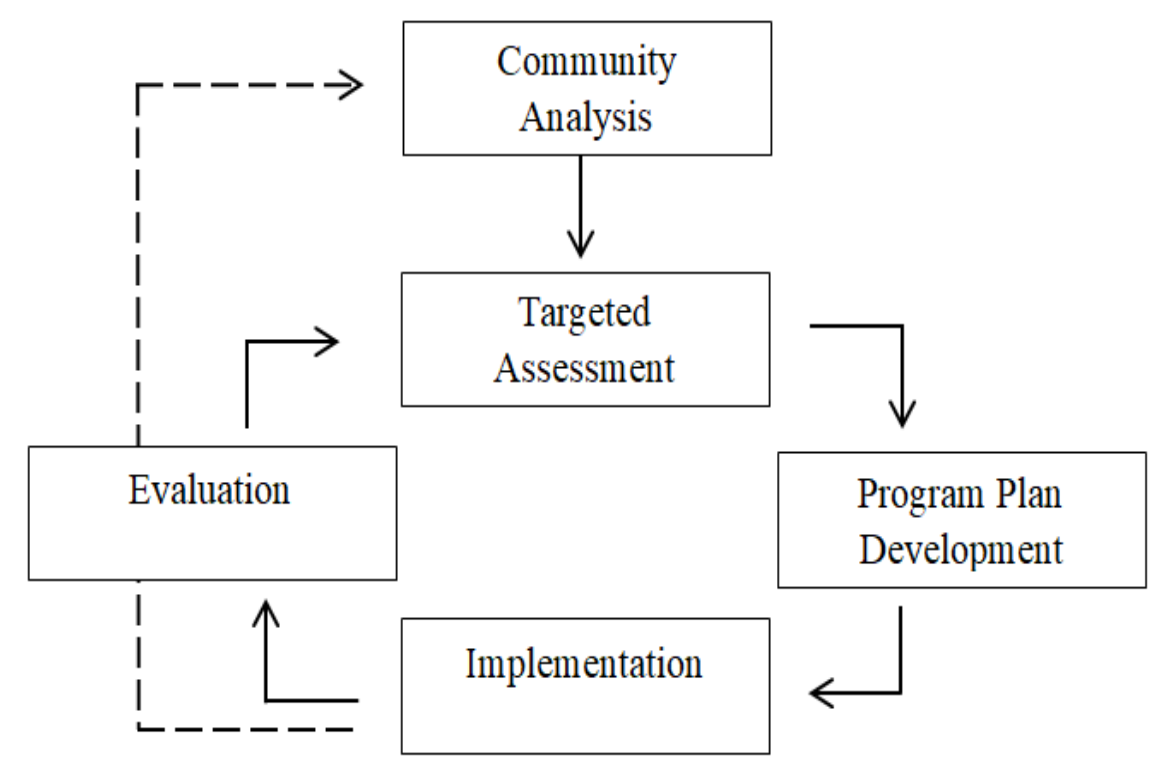

Sumber : Dignan \& Carr (1992) ${ }^{9}$

[Gambar 1]. Skema Perencanaan Program berdasar Kerangka Teori Dignan 